\title{
Identification of $\mathrm{Mn}$ (II)-Oxidizing Bacteria from a Low-pH Contaminated Former Uranium Mine
}

\author{
Denise M. Akob, ${ }^{\text {a,b }}$ Tsing Bohu, ${ }^{a}$ Andrea Beyer, ${ }^{\text {a* }}$ Franziska Schäffner, $^{c}$ Matthias Händel, ${ }^{c}$ Carol A. Johnson, ${ }^{d}$ Dirk Merten, ${ }^{c}$ \\ Georg Büchel, ${ }^{\mathrm{c}}$ Kai Uwe Totsche, ${ }^{\mathrm{c}}$ Kirsten Küsel ${ }^{\mathrm{a}, \mathrm{e}}$ \\ Institute of Ecology, Friedrich Schiller University Jena, Jena, Germanya; U.S. Geological Survey, National Research Program, Reston, Virginia, USA ; Institute of Geosciences, \\ Friedrich Schiller University Jena, Jena, Germanyc; Department of Geosciences, Virginia Tech, Blacksburg, Virginia, USA ; German Centre for Integrative Biodiversity \\ Research, Halle-Jena-Leipzig, Leipzig, Germanye
}

Biological Mn oxidation is responsible for producing highly reactive and abundant Mn oxide phases in the environment that can mitigate metal contamination. However, little is known about Mn oxidation in low-pH environments, where metal contamination often is a problem as the result of mining activities. We isolated two Mn(II)-oxidizing bacteria (MOB) at pH 5.5 (Duganella isolate $\mathrm{AB} \_14$ and Albidiferax isolate TB-2) and nine strains at $\mathrm{pH} 7$ from a former uranium mining site. Isolate TB-2 may contribute to $\mathrm{Mn}$ oxidation in the acidic Mn-rich subsoil, as a closely related clone represented $16 \%$ of the total community. All isolates oxidized $\mathrm{Mn}$ over a small $\mathrm{pH}$ range, and isolates from low-pH samples only oxidized Mn below pH 6. Two strains with different $\mathrm{pH}$ optima differed in their Fe requirements for Mn oxidation, suggesting that Mn oxidation by the strain found at neutral $\mathrm{pH}$ was linked to $\mathrm{Fe}$ oxidation. Isolates tolerated $\mathrm{Ni}, \mathrm{Cu}$, and $\mathrm{Cd}$ and produced $\mathrm{Mn}$ oxides with similarities to todorokite and birnessite, with the latter being present in subsurface layers where metal enrichment was associated with Mn oxides. This demonstrates that MOB can be involved in the formation of biogenic Mn oxides in both moderately acidic and neutral $\mathrm{pH}$ environments.

O xidation of soluble $\mathrm{Mn}(\mathrm{II})$ to insoluble $\mathrm{Mn}(\mathrm{III}, \mathrm{IV})$ oxide minerals, although thermodynamically favored, tends to be slow in natural environments (1). Microorganisms, bacteria and fungi, catalyze $\mathrm{Mn}$ oxidation and increase the reaction rate by several orders of magnitude relative to abiotic reactions (1-3). Therefore, environmental Mn oxides, such as birnessite, are presumed to be of biological origin, e.g., biogenic (3). Mn(II)-oxidizing bacteria $(\mathrm{MOB})$ are phylogenetically diverse and are detected in many different environments, such as soils, water (fresh to marine), and sediments (4). While microorganisms readily oxidize $\mathrm{Mn}(\mathrm{II})$ and precipitate $\mathrm{Mn}$ oxides at $\mathrm{pH} \sim 7$ under oxic and hypoxic conditions (5), little is known about biological oxidation at acidic $\mathrm{pH}$. Under these conditions, chemical Mn oxidation with oxygen is predicted to be thermodynamically unfavorable and $\mathrm{Mn}$ (II) is stable in the environment $(2,5-7)$. All MOB isolated to date are neutrophiles, including the model organisms Roseobacter sp. AzwK-3b (8), Bacillus sp. SG-1 (9), Leptothrix sp (10), Pseudomonas putida GB-1 (11), and Aurantimonas manganoxydans (12), and have been studied for mechanisms of Mn oxidation and biomineral formation. The only reports of microbial Mn oxidization at low $\mathrm{pH}$ have come from the work of Bromfield, who analyzed cell extracts of Streptomyces spp. (13) and soil microorganisms (14) that oxidized $\mathrm{Mn}(\mathrm{II})$ at $\mathrm{pH}$ levels of $<6$, and from Ivarson, who reported that the fungus Cephalosportium sp. oxidized $\mathrm{Mn}(\mathrm{II})$ at $\mathrm{pH} 4.5$ (15). Although to the best of our knowledge no MOB has been isolated from low- $\mathrm{pH}$ environments, there is evidence for biologically driven Mn oxidation at $\mathrm{pH}$ levels of $<7$ in the environment, such as that observed by Sparrow (16) for acidic soils.

Mn oxidation is catalyzed by heterotrophic organisms, and both direct and indirect mechanisms are identified for Mn oxidation (as summarized in reference 2). Indirect mechanisms are when the microbe modifies the $\mathrm{pH}$ or redox of the local environment or releases a chemical oxidant for $\mathrm{Mn}$, such as superoxide
(17). Direct oxidation, on the other hand, can occur via the production of polysaccharides or enzymatic activity (as summarized in reference 2). Although $\mathrm{Mn}(\mathrm{IV})$ formation could generate energy for organisms, this has not been definitively shown for any organism $(4,5)$. However, Mn oxidation was shown to increase the survival of Pseudomonas putida GB-1 in the presence of reactive oxygen species (ROS) (18). In addition, Mn oxidation has been speculated to provide other advantages to the cell, such as abiotic oxidation of refractory organic matter by Mn oxides (3) or controlling the availability of toxic metal ions $(2,3,19)$. Biogenic Mn oxides are effective metal sorbents (2, 20-23), with two to five times more $\mathrm{Pb}$-adsorbing capacities than abiotic Mn oxides and crystalline $\mathrm{MnO}_{2}$ minerals (20). However, this previous work was performed with model microorganisms cultivated at neutral $\mathrm{pH}$, and little is known about the advantages of MOB in low-pH metal-contaminated environments.

In the former uranium mining area near Ronneburg, Germany, there is evidence for the natural attenuation of metal contaminants in Mn-rich subsurface layers with $\mathrm{pH}$ levels of 4 to 5 (24-26). In these layers, metal contaminants (e.g., Cd, Ni, and Co) are primarily associated with Mn oxides (24), suggesting a role for

Received 18 April 2014 Accepted 2 June 2014

Published ahead of print 13 June 2014

Editor: C. R. Lovell

Address correspondence to Denise M. Akob, dakob@usgs.gov.

* Present address: Andrea Beyer, Institute for Microbiology, Friedrich Schiller University Jena, Jena, Germany.

Supplemental material for this article may be found at $h t t p: / / d x . d o i . o r g / 10.1128$ /AEM.01296-14.

Copyright $\odot 2014$, American Society for Microbiology. All Rights Reserved. doi:10.1128/AEM.01296-14 
the oxides as geochemical barriers, with selected elements retained in local epigenetic zones of soils or sediments inhibiting further transport of such elements (27). Thus, it is important to determine the mechanisms behind the formation of these geochemical barriers in order to maintain the status quo or exploit the attenuation process for more widespread remediation of contaminants. We hypothesized that MOB contribute to the formation of Mn oxides and are thereby affecting the fate of metals in the Ronneburg mining area. Therefore, we aimed in this study to (i) isolate MOB from the contaminated mining site at a variety of $\mathrm{pH}$ levels, (ii) evaluate the biological formation of Mn oxides, and (iii) characterize microbial communities associated with Mn oxide-rich geochemical barriers.

\section{MATERIALS AND METHODS}

Site and sampling description. The study sites are located within the former Ronneburg uranium mining district in Thuringia, Germany. Uranium was leached from low-grade black shale with acid mine drainage (AMD) and sulfuric acid from the 1970s to 1989, and this resulted in widespread environmental contamination with acid mine drainage and high concentrations of metals. Physical remediation was completed in 2004 , although contaminated groundwater still threatens nearby ecosystems; for a more detailed description of the site history, see references 25 , 26, 28, and 29. Contaminated Mn-rich samples were collected in 2010 from three locations: the Gessenwiese test field (GTF; location E 4510469, N 5635476 [Gauss-Krueger Potsdam coordinate system]), the bed of the Gessen Creek (R3; location E 4510271, N 5635859), and soil material from the Gessen Creek bank (B; location, E 4510121, N 5635807), as shown in Fig. S1 in the supplemental material. A soil depth profile was excavated at the GTF a few meters southeast from the formerly described profile of Burkhardt et al. (24), and soil materials were collected from three layers: an Mn-rich layer (gray-black soil layer located at a depth of 56 to $70 \mathrm{~cm}$ ), top (above the Mn layer), and bottom (reddish soil layer below the Mnrich layer) (see Fig. S1). The Gessen Creek location was chosen for study as it is located downhill from the former leaching heap (site GTF) and is currently receiving contaminated groundwater inputs due to flooding of the former mines. Samples from site GTF were used for geochemical characterization, microbial community characterization, and isolation; the soil solution was collected from water-saturated subsurface layers by using Rhizon dialysis samplers. Site R3 and B samples were used for isolation and geochemical characterization. Samples for microbial analyses were collected aseptically and stored at $4^{\circ} \mathrm{C}$ until analysis or stored at $-80^{\circ} \mathrm{C}$ for microbial community characterization.

Geochemical characterization. The redox potential $\left(\mathrm{E}_{\mathrm{h}}\right)$ was measured in situ by using a Pt4800-M5-S7/80 redox probe (Mettler-Toledo). At site R3, the $\mathrm{pH}$ was measured in situ, whereas for sites B and GTF the $\mathrm{pH}$ of the soil and sediment was measured by the $\mathrm{CaCl}_{2}$ method as previously described (30). Total element content was determined for air-dried, sieved $(<2 \mathrm{~mm})$, and mortared sediment and soil samples after digestion using ICP-OES (inductively coupled plasma-optical emission spectrometry; 725 ES; Varian) and ICP-MS (inductively coupled plasma-mass spectrometry; XSeries II; Thermo Fisher Scientific), as previously described (24). Total organic carbon (TOC) was measured with a CN analyzer (varioMAXCN; Elementar, Germany) as previously described (31). Soil solution samples were collected by using miniature plastic suction cups (ecoTech). Samples were filtered directly $(<0.2 \mu \mathrm{m})$ via the polymeric membrane of the suction tubes. Samples for cation analysis were additionally acidified with $\mathrm{HNO}_{3}$ (68\%; Suprapur; Merck) to a $\mathrm{pH}$ of $<2$. The solutions were then analyzed using ICP-OES and ICP-MS.

Isolation of $\mathrm{Mn}(\mathrm{II})$-oxidizing bacteria. Soil and sediment samples were serially diluted $\left(10^{-1}\right.$ to $\left.10^{-5}\right)$ in $0.7 \% \mathrm{NaCl}$, and $100 \mu \mathrm{l}$ of each dilution was plated onto three types of $\mathrm{MnCO}_{3}$-containing agar at $\mathrm{pH} 5.5$, 6.5, or 7.0. Basic $\mathrm{MnCO}_{3}$ agar (BM; modified Leptothrix medium [32]) contained (per liter): $2.0 \mathrm{~g} \mathrm{MnCO}_{3}, 0.5 \mathrm{~g}$ meat extract, $0.5 \mathrm{~g}$ yeast extract,
$0.28 \mathrm{~g} \mathrm{Fe}\left(\mathrm{NH}_{4}\right)_{2}\left(\mathrm{SO}_{4}\right)_{2} \cdot 6 \mathrm{H}_{2} \mathrm{O}, 0.17 \mathrm{~g}$ sodium citrate, $5.0 \mu \mathrm{g}$ vitamin $\mathrm{B}_{12}, 2$ $\mathrm{ml}$ trace element solution SL9 (33), and $50 \mathrm{mg}$ cycloheximide (to inhibit fungal growth). BM7 refers to plates at $\mathrm{pH} 7.0$ buffered with $10 \mathrm{mM}$ HEPES ( $\mathrm{pH}$ 7.0), whereas BM5.5 refers to plates at $\mathrm{pH} 5.5$ buffered with $10 \mathrm{mM}$ morpholineethanesulfonic acid (MES). All plates were incubated at $15^{\circ} \mathrm{C}$ in the dark.

MOB were identified by using leucoberbelin blue (LBB) and benzidine, which react with $\mathrm{Mn}(\mathrm{III} / \mathrm{IV}$ ) oxides, in colorimetric assays (34). In brief, a drop of the LBB or benzidine reagent was applied directly to a brownish-black colony, and the mixture was incubated for $20 \mathrm{~min}$ at room temperature in the dark prior to a visual inspection for color change. An additional spot of reagent was placed on a spare area of the same agar plate as a control for abiotic oxidation. No quantification was possible with the visual method.

LBB-positive colonies were transferred at least 5 times, and purity was controlled based on colony morphology. $\mathrm{pH}$ was monitored before and after incubation in the medium by homogenizing a subsample of the agar medium from plates and then using a pH electrode. No change in the bulk $\mathrm{pH}$ of the medium was observed during the time of incubation (1 week to 3 months).

Isolate $16 \mathrm{~S}$ rRNA gene analysis. Genomic DNA was isolated from pure cultures by boiling a loopful of bacterial cells in $100 \mu 15 \%$ Chelex 100 solution (Bio-Rad) for $10 \mathrm{~min}$. After $2 \mathrm{~min}$ of centrifugation at full speed, the supernatant was used as the template for PCR amplification. 16S rRNA genes were amplified with the universal primers $27 \mathrm{~F}$ and $1492 \mathrm{R}$, as previously described (35). Isolates were screened by amplified rRNA gene restriction analysis (ARDRA), and representative operational taxonomic units (OTUs) were chosen for Sanger sequencing (performed at Macrogen, Inc., South Korea and The Netherlands). Sequences were assembled using Geneious Pro version 4.6.4 (36), and isolates were grouped together if colony morphologies were identical and 16S rRNA gene sequences had $>97 \%$ sequence similarity. Sequence identity was determined using the BLAST algorithm against the GenBank database available from NCBI (37). The closest type strains to the representative strains were determined by using the EzTaxon server (38). Sequences were aligned using the Fast Aligner algorithm within the ARB software package (39). Phylogenetic trees incorporating a Jukes-Cantor distance correction with the neighborjoining algorithm and 1,000 bootstrap replicates were constructed using Geneious v5.6.5 (36).

pH and metal tolerance. The $\mathrm{pH}$ ranges for growth and $\mathrm{Mn}(\mathrm{II})$ oxidation were determined in $\mathrm{BM}$ agar plates with the $\mathrm{pH}$ adjusted to 4.0, 5.0, $5.5,6.0,7.0$, or 8.0 with $\mathrm{NaOH}$ or $\mathrm{HCl}$ and without the addition of a buffer. Isolates were plated in triplicate and incubated at $15^{\circ} \mathrm{C}$ in the dark. $\mathrm{pH}$ was monitored before and after incubation (growth) in the bulk medium, as described above, for control and inoculated plates, and no change in the $\mathrm{pH}$ was observed. Growth was monitored visually based on the appearance of colonies. $\mathrm{Mn}$ (II) oxidation was confirmed via the LBB and benzidine spot tests, as described above.

Isolates AB_14, AB_18, and TB-2 were evaluated for their tolerance to 3 concentrations of cadmium, copper, and nickel in liquid medium. Liquid BM medium was prepared as described above without agar and with $100 \mu \mathrm{M} \mathrm{MnCl}_{2}$ instead of $\mathrm{MnCO}_{3}$ as the $\mathrm{Mn}(\mathrm{II})$ source. $\mathrm{AB} \_14$ and TB-2 were cultivated at $\mathrm{pH} 5.5$ with MES as a buffer, whereas AB_18 was cultivated at $\mathrm{pH} 7.0$ with HEPES as a buffer. Cadmium was added to growth media at final concentrations of $0.01,0.05$, and $0.5 \mathrm{mM}$; copper was added at final concentrations of $0.01,0.05$, and $1.0 \mathrm{mM}$; nickel was added to final concentrations of $0.1,1.0$, and $2.0 \mathrm{mM}$. Cultures were grown in triplicate with metals added to the liquid BM medium, and growth was monitored based on the optical density at $600 \mathrm{~nm}\left(\mathrm{OD}_{600}\right)$ measurements on a DR6000 UV-Vis spectrophotometer (Hach Lange GmbH, Germany). $\mathrm{Mn}(\mathrm{II})$ oxidation was evaluated by measuring the formation of Mn oxides in a quantitative LBB colorimetric assay after $742 \mathrm{~h}$ of growth (40). In brief, a $0.1-\mathrm{ml}$ culture sample was added to $0.5 \mathrm{ml}$ of $0.04 \%$ leucoberbelin blue in $45 \mathrm{mM}$ acetic acid and the mixture was incubated for $10 \mathrm{~min}$ in the dark at room temperature. The reaction was filtered $(0.22 \mu \mathrm{m})$, and then 
TABLE $1 \mathrm{Mn}(\mathrm{II})$-oxidizing bacterial strains isolated from the former uranium mining district Ronneburg

\begin{tabular}{|c|c|c|c|c|c|c|}
\hline Sampling location ${ }^{a}$ & $\begin{array}{l}\text { Representative } \\
\text { strain }\end{array}$ & $\begin{array}{l}\text { Accession } \\
\text { no. }\end{array}$ & $\begin{array}{l}\text { No. of } \\
\text { isolates }\end{array}$ & $\begin{array}{l}\text { Soil } \\
\text { dilution }\end{array}$ & $\begin{array}{l}\mathrm{pH} \text { of } \\
\text { isolation }\end{array}$ & $\begin{array}{l}\text { Closest type strain }{ }^{b} \\
\text { (accession no., \% identity) }\end{array}$ \\
\hline \multirow[t]{2}{*}{ Gessen Creek site R3 } & AB_9 & JQ033389 & 3 & $10^{-4}$ & 7.0 & Duganella zoogloeoides IAM $12670^{\mathrm{T}}$ (D14256, 97.8) \\
\hline & $\mathrm{AB}_{-}{ }^{-} 14$ & JQ033393 & 1 & $10^{-1}$ & 5.5 & Duganella zoogloeoides IAM $12670^{\mathrm{T}}$ (D14256, 97.8) \\
\hline \multirow[t]{4}{*}{ Gessen Creek site B } & $\mathrm{AB} \_7$ & JQ033387 & 1 & $10^{-1}$ & 7.0 & Janthinobacterium lividum DSM1522 $2^{\mathrm{T}}$ (Y08846, 99.6) \\
\hline & $\mathrm{AB} \_8$ & JQ033388 & 2 & $10^{-1}$ & 7.0 & Flavobacterium aquidurense WB-1.1.56 ${ }^{\mathrm{T}}$ (AM177392, 98.2) \\
\hline & $A B \_11$ & JQ033385 & 1 & $10^{-1}$ & 7.0 & Janthinobacterium lividum DSM1522 $2^{\mathrm{T}}(\mathrm{Y} 08846,100)$ \\
\hline & $\mathrm{AB}_{-} 13$ & JQ033386 & 1 & $10^{-1}$ & 7.0 & Pseudomonas putida PhyCEm-187 (AM921634, 99.7) \\
\hline \multirow{4}{*}{$\begin{array}{l}\text { Former leaching heap site } \\
\text { GTF, Mn-rich layer }\end{array}$} & AB_17 & JQ033390 & 7 & $10^{-1}$ & 7.0 & Burkholderia sordidicola S5-B ${ }^{\mathrm{T}}$ (AF512826, 98.4) \\
\hline & AB_18 & JQ033391 & 6 & $10^{-1}$ & 7.0 & Arthrobacter stackebrandtii CCM $2783^{\mathrm{T}}$ (AJ640198, 97.5) \\
\hline & TB-1 & HG423345 & 1 & $10^{-2}$ & 7.0 & Frigoribacterium sp. LPPA 548 (HE613773, 100) \\
\hline & TB-2 & HG003356 & 1 & $10^{-2}$ & 5.5 & Albidiferax ferrireducens T118 (CP000267, 99) \\
\hline
\end{tabular}

${ }^{a}$ Samples were collected from three locations within the former uranium mining district Ronneburg: the Gessenwiese test field (GTF), the bed of the Gessen Creek (R3), and soil material from the Gessen Creek bank (B) (see Fig. S1 in the supplemental material).

${ }^{b}$ The type strains closest to the representative strains were determined by using the EzTaxon server (38).

the absorbance was measured at $620 \mathrm{~nm}$ on a Hach DR6000 UV-Vis spectrophotometer. Standard curves were constructed with $\mathrm{KMnO}_{4} . \mathrm{Mn}$ oxides in control cultures (medium alone with metals added) were also measured, in order to account for background interactions between the medium and the metals. The data presented represent the amount of Mn oxide produced in the presence of bacteria minus the measured Mn oxide in control cultures.

LA-ICP-MS. Elemental distributions within colonies of MOB strains were determined qualitatively by using laser ablation-inductively coupled plasma-mass spectrometry (LA-ICP-MS). Six Gessen Creek strains ( $\mathrm{AB} \_7, \mathrm{AB} \_8, \mathrm{AB} \_9, \mathrm{AB} \_11, \mathrm{AB} \_13$, and $\mathrm{AB} \_14$ ) were inoculated onto $\mathrm{MnCO}_{3}$ agar with the same conditions used for isolation by streaking inoculum over the whole plate in a zigzag pattern and incubated for 2 weeks at $15^{\circ} \mathrm{C}$. Additional plates were prepared for $\mathrm{AB} \_9$ and $\mathrm{AB} \_14$ without $\mathrm{Fe}$ in the medium to evaluate the influence of $\mathrm{Fe}$ on $\mathrm{Mn}$ oxidation. Agar plates were dried at $40^{\circ} \mathrm{C}$ in a drying oven for 7 to 21 days, until an even, flat surface with a thickness of $\sim 100 \mu \mathrm{m}$ was obtained. Sections of dried agar ( 4 by $2 \mathrm{~cm}$ ) were excised from the plate and fixed on a microscope slide with double-sided adhesive tape. Profiles (length, 2.5 to 3.1 $\mathrm{cm})$ covering biomass and agar alone were ablated with an Nd:YAG laser (Microprobe II; Merchantek, Fremont, CA) coupled to an X-Series II ICP-MS apparatus (Thermo Fisher Scientific, Bremen, Germany). All scans were normalized to carbon $\left({ }^{13} \mathrm{C}\right)$ as an internal standard.

FTIR spectroscopy. Samples of MOB biomass collected from agar plates and uninoculated agar were freeze-dried at $-60^{\circ} \mathrm{C}$ and then ground into a fine powder for Fourier-transform infrared (FTIR) spectroscopy. FTIR spectra were recorded using a Nicolet iS10 spectrometer (Thermo Fisher Scientific, Dreieich, Germany). Mortared samples were mixed with $\mathrm{KBr}$ at a ratio of 1:100 and pressed into pellets. The pellets were studied in transmission mode in the mid-infrared range, between 4,000 and 400 $\mathrm{cm}^{-1}$, for a total of 16 scans at a resolution of $4 \mathrm{~cm}^{-1}$. Spectra were baseline corrected by subtracting a straight line running between the two minima of each spectrum and normalized by dividing each data point by the spectrum's maximum.

Transmission electron microscopy. For transmission electron microscropy (TEM), the MOB biomass was collected from agar plates and fixed in a freshly prepared, $0.2-\mu \mathrm{m}$-pore filter-sterilized solution of $2.5 \%$ glutaraldehyde (electron microscopy grade; Roth) in phosphatebuffered saline (PBS) buffer. Cell suspensions were centrifuged to a pellet at $16,000 \times g$ for $5 \mathrm{~min}$ and brought to the Electron Microscopy Center at the University Clinic in Jena, Germany, for resin embedding and ultramicrotomy. In brief, the samples were washed three times with PBS buffer, stained with $1 \% \mathrm{OsO}_{4}$ in triply distilled water, and washed again three times with PBS buffer. Two dehydration steps of 30 and 50\% ethanol were followed by $2 \%$ uranyl acetate in $50 \%$ alcohol (for staining) and four dehydration steps of 50\%, 70\%, 96\%, and 100\% ethanol. Absolute dehydration was guaranteed with propylene oxide before embedding with araldite resin (1:2, 1:1, 2:1, and 100\% araldite:propylene oxide steps). Resin-embedded samples were cured at $60^{\circ} \mathrm{C}$ before slicing to a 50 - to 80-nm thickness with an Ultratome III (LKB, Stockholm, Sweden). Ultramicrotomed resin slices were placed on Cu TEM grid films, poststained with lead citrate, and analyzed on a variety of TEMs, including a Zeiss EM 900 operated at $80 \mathrm{kV}$ (with digitized photo film), an FEI Tecnai G2 operated at $200 \mathrm{kV}$, and an FEI Titan operated at $300 \mathrm{kV}$ in STEM mode. In addition to images, elemental information was obtained by energydispersive X-ray spectroscopy (EDS), and structural information was obtained by selected area electron diffraction (SAED). Analysis times, especially on the $300-\mathrm{kV}$ TEM, were kept to a minimum due to the occurrence of beam damage (loss of mineral crystallinity and unstable resin) within a few minutes.

Microbial community 16S rRNA gene analysis and quantitative PCR. DNA was extracted from $1 \mathrm{~g}$ of subsurface soil from the top (above the Mn-rich layer), Mn (Mn-rich layer), and bottom (below the Mn-rich layer) layers according to the method of Zhou et al. (41). Genomic DNA was PCR amplified with universal bacteria primers $27 \mathrm{~F}$ and 1492R, which target the 16S rRNA gene, as described above. PCR amplicons were purified and then cloned into the pGEM T-Easy vector according to the manufacturer's instructions (Promega). Clone PCR was performed with M13F/R primers, and positive clones were Sanger sequenced with the universal 907R primer at Macrogen, Inc. (South Korea and The Netherlands). Sequences were trimmed by using Geneious Pro version 4.6.4 (36). OTUs (based on a 97\% sequence similarity cutoff), taxonomic affiliation, and statistical analyses were performed within mothur (42).

Total bacteria and Albidiferax ferrireducens were quantified using quantitative PCR (qPCR) targeting universal bacterial 16S rRNA genes with the primers Uni-338F-RC and Uni-907R (43) and Albidiferax ferrireducens-specific primers Rdo R-RC (modified from reference 44) and Uni-907R, respectively. Purified genomic DNA (10 ng) was used as the template in the Maxima SYBR green qPCR master mix (Fermentas, Germany). Plasmids CB54 (accession number HE604015) and NR27 (accession number HE604080) were used as standards (45). Thermocycling was performed with the following temperature program: $10 \mathrm{~min}$ at $95^{\circ} \mathrm{C}$ and 50 cycles of $30 \mathrm{~s}$ at $95^{\circ} \mathrm{C}, 45 \mathrm{~s}$ at $57^{\circ} \mathrm{C}, 60 \mathrm{~s}$ at $72^{\circ} \mathrm{C}$, and $10 \mathrm{~s}$ at $78^{\circ} \mathrm{C}$. Fluorescence measurements were made at 61,72 , and $78^{\circ} \mathrm{C}$ for each cycle, followed by a dissociation curve analysis with $1 \mathrm{~min}$ at $95^{\circ} \mathrm{C}, 30 \mathrm{~s}$ at $55^{\circ} \mathrm{C}$, and heating to $95^{\circ} \mathrm{C}$ at a rate of $0.01^{\circ} \mathrm{C} \mathrm{s}^{-1}$.

Nucleotide sequence accession numbers. The $16 \mathrm{~S}$ rRNA gene sequences of isolates obtained in this study were deposited in the GenBank or EMBL database under the accession numbers JQ033385 (AB_11), JQ033386 (AB_13), JQ033387 (AB_7), JQ033388 (AB_8), JQ033389 


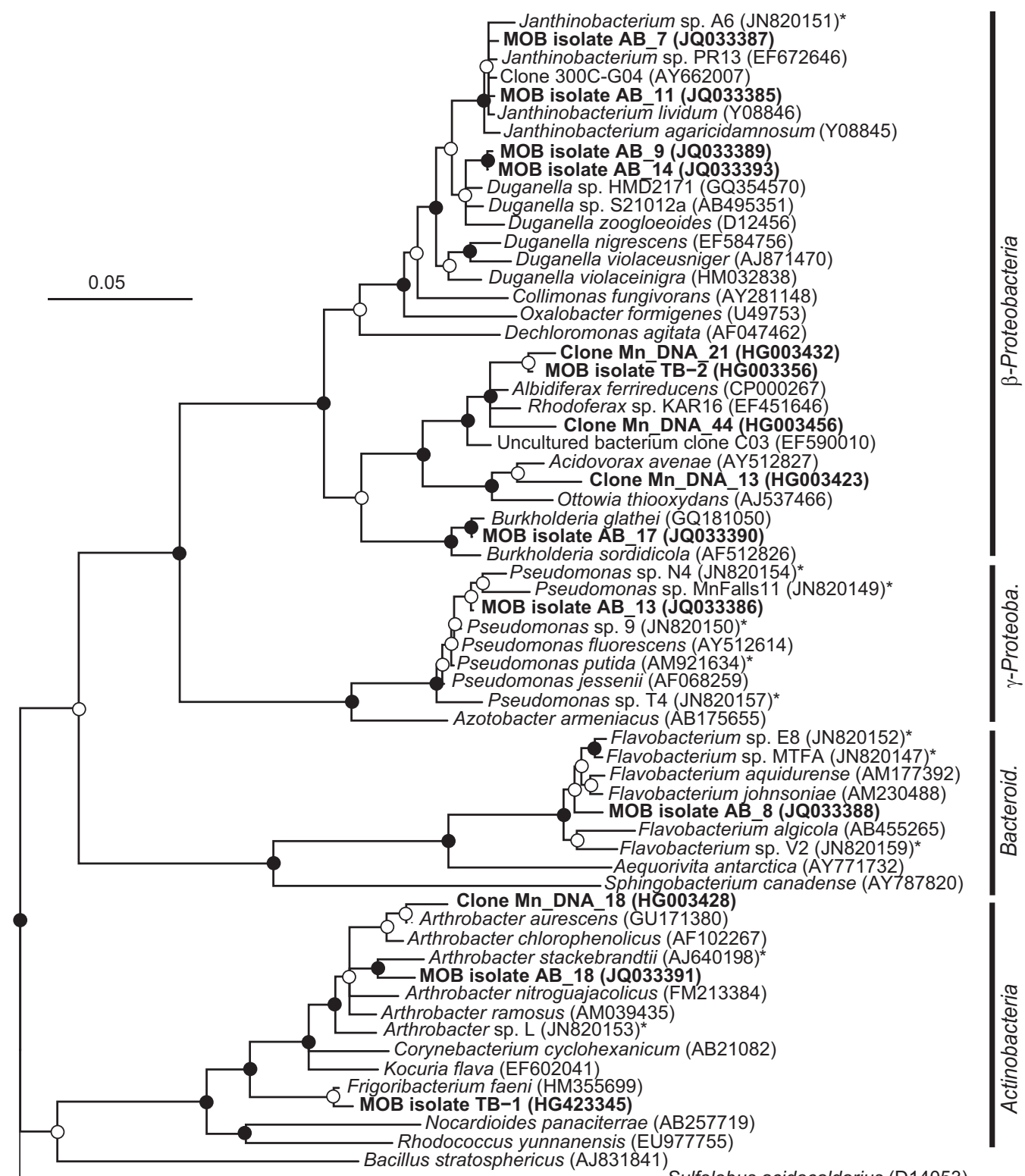

FIG 1 Neighbor-joining phylogenetic tree of 16S rRNA gene sequences of Mn(II)-oxidizing bacterial isolates and related clone sequences obtained from Mn-rich soil (indicated by boldface type). Isolates are designated by MOB followed by the strain number; clones are designated by Mn_DNA followed by the clone number. Known MOB are designated with an asterisk. Sulfolobus acidocaldarius was used as the outgroup. Branch points supported by bootstrap resampling (1,000 replicates) are indicated by filled circles (bootstrap values of $>90 \%$ ) and open circles (bootstrap values of $>50 \%$ ). Bar, 0.05 change per nucleotide position. Bacteroid., Bacteroidetes; $\gamma$-Proteob., Gammaproteobacteria.

(AB_9), JQ033390 (AB_17), JQ033391 (AB_18), JQ033393 (AB_14), HG423345 (TB-1) and HG003356 (TB-2). Sequences obtained from total microbial community analysis were deposited in the EMBL database under accession numbers HG003357 to HG003566.

\section{RESULTS AND DISCUSSION}

Isolation of Mn-oxidizing bacteria. A total of $24 \mathrm{MOB}$ isolates were obtained from three sites within the former Ronneburg uranium mining area (see Fig. S1 in the supplemental material): the Mn-rich geochemical barrier from the Gessenwiese test field (GTF), the sediment of the Gessen Creek (R3), and topsoil material from the Gessen Creek bank (B). These sites were predicted to vary in their favorability for the growth of Mn oxidizers, based on their $\mathrm{pH}$ and organic carbon contents. The Mn-rich soil layer obtained from a depth of 56 to $70 \mathrm{~cm}$ at site GTF contained 33,000 $\mu \mathrm{g}$ Mn per $\mathrm{g}$ of soil (see Fig. S2 in the supplemental material) had a $\mathrm{pH}$ of 4.8 , and hydrous Mn oxides were detected by FTIR spectroscopy (26). Sites R3 and B at the Gessen Creek had neutral $\mathrm{pH}(\mathrm{pH} 6.3)$ and higher TOC contents ( $\mathrm{R} 3,3.9 \%$ TOC [31]; B, 5.4\% TOC [46]) than site GTF (0.26\% TOC) and therefore were predicted to favor growth of neutrophilic heterotrophic MOB. Site R3 sediment contained $667 \mu \mathrm{g}$ of Mn/g of sediment (31), whereas site B contained $884 \mu \mathrm{g}$ of Mn per g of soil. Analysis of $16 \mathrm{~S}$ rRNA genes grouped these isolates into 10 representative strains (Table 1 ). 
TABLE $2 \mathrm{pH}$ ranges for growth and Mn oxidation by MOB isolates ${ }^{a}$

\begin{tabular}{|c|c|c|c|c|c|c|}
\hline \multirow[b]{2}{*}{ Strain } & \multirow{2}{*}{$\begin{array}{l}\mathrm{pH} \text { of } \\
\text { isolation }\end{array}$} & \multicolumn{5}{|c|}{$\mathrm{pH}$ range tolerated ${ }^{b}$} \\
\hline & & 5.0 & 5.5 & 6.0 & 7.0 & 8.0 \\
\hline AB_7 & 7.0 & $-/ \mathrm{LBB}^{-}$ & $-/ \mathrm{LBB}^{-}$ & $-/ \mathrm{LBB}^{-}$ & $+/ \mathrm{LBB}^{+}$ & $-/ \mathrm{LBB}^{-}$ \\
\hline AB_11 & 7.0 & $-/ \mathrm{LBB}^{-}$ & $-/ \mathrm{LBB}^{-}$ & $-/ \mathrm{LBB}^{-}$ & $+/ \mathrm{LBB}^{+}$ & $+/ \mathrm{LBB}^{-}$ \\
\hline AB_9 & 7.0 & $-/ \mathrm{LBB}^{-}$ & $-/ \mathrm{LBB}^{-}$ & $-/ \mathrm{LBB}^{-}$ & $+/ \mathrm{LBB}^{+}$ & $+/ \mathrm{LBB}^{-}$ \\
\hline AB_17 & 7.0 & $-/ \mathrm{LBB}^{-}$ & $-/ \mathrm{LBB}^{-}$ & $-/ \mathrm{LBB}^{-}$ & $+/ \mathrm{LBB}^{+}$ & $-/ \mathrm{LBB}^{-}$ \\
\hline AB_13 & 7.0 & $-/ \mathrm{LBB}^{-}$ & $-/ \mathrm{LBB}^{-}$ & $-/ \mathrm{LBB}^{-}$ & $+/ \mathrm{LBB}^{+}$ & $-/ \mathrm{LBB}^{-}$ \\
\hline AB_- 18 & 7.0 & $-/ \mathrm{LBB}^{-}$ & $-/ \mathrm{LBB}^{-}$ & $+/ \mathrm{LBB}^{+}$ & $+/ \mathrm{LBB}^{+}$ & $+/ \mathrm{LBB}^{+}$ \\
\hline TB-1 & 7.0 & $-/ \mathrm{LBB}^{-}$ & $-/ \mathrm{LBB}^{-}$ & $-/ \mathrm{LBB}^{-}$ & $+/ \mathrm{LBB}^{+}$ & $-/ \mathrm{LBB}^{-}$ \\
\hline AB_8 & 7.0 & $-/ \mathrm{LBB}^{-}$ & $-/ \mathrm{LBB}^{-}$ & $-/ \mathrm{LBB}^{-}$ & $+/ \mathrm{LBB}^{+}$ & $-/ \mathrm{LBB}^{-}$ \\
\hline AB_14 & 5.5 & $+/ \mathrm{LBB}^{+}$ & $+/ \mathrm{LBB}^{+}$ & $+/ \mathrm{LBB}^{-}$ & $+/ \mathrm{LBB}^{-}$ & $-/ \mathrm{LBB}^{-}$ \\
\hline TB-2 & 5.5 & $-/ \mathrm{LBB}^{-}$ & $+/ \mathrm{LBB}^{+}$ & $+/ \mathrm{LBB}^{+}$ & $+/ \mathrm{LBB}^{-}$ & $-/ \mathrm{LBB}^{-}$ \\
\hline
\end{tabular}

${ }^{a}$ Isolates were incubated on BM medium adjusted to different $\mathrm{pHs}$; the $\mathrm{pH}$ levels remained stable during incubation.

${ }^{b}$ Growth (+, colonies present after 1 month of incubation) or no growth (-, no colonies present after 1 month)/presence $\left(\mathrm{LBB}^{+}\right)$or absence $\left(\mathrm{LBB}^{-}\right)$of $\mathrm{Mn}$ oxides in LBB spot test.

Two of the representative MOB strains were isolated at $\mathrm{pH} 5.5$ (strains AB_14 and TB-2 within the Betaproteobacteria), whereas the other eight strains were isolated at pH 7 (members of the Betaand Gammaproteobacteria, Actinobacteria, Bacteroidetes, and Firmicutes phyla) (Table 1 and Fig. 1). All isolated strains oxidized $\mathrm{Mn}$, as shown by a positive LBB spot test, and Mn accumulation around colony biomass, as observed using LA-ICP-MS (Fig. 3). The $\mathrm{pH}$ did not change in the bulk medium during incubation.

The low-pH isolate TB-2 was a member of the Comamonadaceae family, whereas strain AB_14 fell into the Oxalobacteraceae family. TB-2 was most closely related to Albidiferax ferrireducens $\mathrm{T} 118$ (99\% sequence identity) (Table 1), which is a known Fe(III) reducer $(47,48)$ that has not been tested for its Mn-oxidizing capacities. However, our strain was not found to reduce $\mathrm{Fe}(\mathrm{III})$ or $\mathrm{Mn}$ (IV) under laboratory conditions (data not shown). As TB-2 is within the Comamonadaceae family, it joins Caldimonas manganoxidans (49) as the second organism within this family that is known to oxidize Mn. Strain AB_14 was most closely related to Duganella zoogloeoides ( $97.8 \%$ sequence identity) (Table 1) within the Oxalobacteraceae family and was also closely related to strain AB_9, which was isolated at pH 7. However, Duganella sp. AB_14 and AB_9 are considered separate strains, as they differ in their $\mathrm{pH}$ range for growth and $\mathrm{Mn}$ oxidation (Table 2 and below). Members of the genus Duganella were not previously shown to oxidize Mn. However, within the Oxalobacteraceae family there is a high degree of phylogenetic similarity between members of the genera Janthinobacterium, Oxalobacter, Duganella, and Herbaspirillum, as shown by DNA-RNA hybridization studies and small-subunit rRNA gene sequence analysis
(50). Recently, Mn oxidation was described for isolate Janthinobacterium sp. A6 (51), which was obtained at neutral $\mathrm{pH}$ from ferromanganese deposits in caves. However, little is known to date of the mechanisms used by members of this family for Mn oxidation.

Of the 8 isolates obtained at $\mathrm{pH} 7$, only two were closely related to well-characterized MOB strains: AB_13 (99\% sequence identity to Pseudomonas putida) and AB_18 (97.5\% sequence identity to Arthrobacter stackebrantii) (Table 1 and Fig. 1). However, strains AB_7 and AB_8 were related to the newly discovered MOB strains Janthinobacterium sp. A6 (99.4\% sequence identity) and Flavobacterium sp. E ( $98 \%$ sequence identity), respectively, suggesting that Mn oxidation may be common in these genera and not limited only to cave environments, where they were first observed to oxidize Mn (51).

Our study further broadens the known phylogenetic diversity of Mn-oxidizing bacteria, as our two low-pH and three neutral-pH MOB isolates were members of genera that were not previously shown to harbor Mn oxidizers. As research on MOB expands, additional phylogenetic groups might be identified. The presence of new phylogenetic groups may indicate the presence of unknown mechanisms for Mn oxidation, especially at low $\mathrm{pH}$.

Physiology and in situ relevance of MOB isolates. Tests for the $\mathrm{pH}$ growth range and $\mathrm{Mn}$ oxidation by the 10 representative strains revealed that only isolates Duganella sp. AB_14, Albidiferax sp. TB-2, and Arthrobacter sp. AB_18 were capable of growing and oxidizing Mn below pH 7.0 (Table 2). AB_14 could grow over 2 $\mathrm{pH}$ units ( $\mathrm{pH} 5.0$ to 7.0) but only oxidized $\mathrm{Mn}$ at $\mathrm{pH} 5.0$ and 5.5. Similarly, TB-2 could grow at pH 5.5, 6.0, and 7.0 but only oxidized $\mathrm{Mn}$ at $\mathrm{pH} 5.5$ and 6.0. Strain AB_18 grew and oxidized Mn at $\mathrm{pH} 6.0$ to 8.0. Thus, we isolated two MOB strains that preferentially oxidize $\mathrm{Mn}$ at low $\mathrm{pH}$ : Albidiferax sp. TB-2 and Duganella sp. AB_14.

Bacterial Mn oxidation at low $\mathrm{pH}$ is unique, as $\mathrm{Mn}$ (II) oxidation under acidic conditions is predicted to be thermodynamically unfavorable (3, 5-7). At neutral to slightly alkaline $\mathrm{pH}$ ( $\mathrm{pH} 7$ to 9), Mn oxidation is thermodynamically favorable but occurs very slowly in the absence of bacteria $(5,6)$. However, to carry out Mn oxidation at low $\mathrm{pH}$ it is expected that a large activation energy is needed, which may not be favorable for a microorganism, especially as Mn oxidation is not thought to provide energy for the cell $(2,5)$.

Metal tolerance of MOB isolates. Metal ions affect the growth and Mn-oxidizing ability of Mn-oxidizing organisms (52). We evaluated the metal tolerance of Duganella sp. AB_14, Albidiferax sp. TB-2, and Arthrobacter sp. AB_18, which can oxidize $\mathrm{Mn}$ at $\mathrm{pH}$ levels that are relevant in situ (Mn-rich soil had a $\mathrm{pH}$ of 4.8; site R3 had a $\mathrm{pH}$ of 6.3). All three isolates grew and oxidized $\mathrm{Mn}$ in the

TABLE 3 Metal tolerance of MOB isolates $\mathrm{AB} \_14, \mathrm{AB} \_18$, and TB-2 in the presence of various concentrations of $\mathrm{Cd}, \mathrm{Cu}, \mathrm{or} \mathrm{Ni}^{a}$

\begin{tabular}{|c|c|c|c|c|c|c|c|c|c|}
\hline \multirow[b]{3}{*}{ Strain } & \multicolumn{9}{|c|}{ Metal tolerance ${ }^{b}$} \\
\hline & \multicolumn{3}{|l|}{$\mathrm{Cd}$} & \multicolumn{3}{|l|}{$\mathrm{Cu}$} & \multicolumn{3}{|l|}{$\mathrm{Ni}$} \\
\hline & $0.01 \mathrm{mM}$ & $0.05 \mathrm{mM}$ & $0.5 \mathrm{mM}$ & $0.01 \mathrm{mM}$ & $0.05 \mathrm{mM}$ & $1.0 \mathrm{mM}$ & $0.1 \mathrm{mM}$ & $1.0 \mathrm{mM}$ & $2.0 \mathrm{mM}$ \\
\hline AB_14 & $+/ \mathrm{LBB}^{-}$ & $-/ \mathrm{LBB}^{-}$ & $-/ \mathrm{LBB}^{-}$ & $+/ \mathrm{LBB}^{+}$ & $+/ \mathrm{LBB}^{+}$ & $-/ \mathrm{LBB}^{-}$ & $+/ \mathrm{LBB}^{+}$ & $-/ \mathrm{LBB}^{-}$ & $-/ \mathrm{LBB}^{-}$ \\
\hline AB_18 & $+/ \mathrm{LBB}^{+}$ & $+/ \mathrm{LBB}^{+}$ & $-/ \mathrm{LBB}^{-}$ & $+/ \mathrm{LBB}^{+}$ & $+/ \mathrm{LBB}^{+}$ & $+/ \mathrm{LBB}^{-}$ & $+/ \mathrm{LBB}^{+}$ & $+/ \mathrm{LBB}^{+}$ & $-/ \mathrm{LBB}^{-}$ \\
\hline TB-2 & $+/ \mathrm{LBB}^{+}$ & $+/ \mathrm{LBB}^{+}$ & $-/ \mathrm{LBB}^{-}$ & $+/ \mathrm{LBB}^{+}$ & $+/ \mathrm{LBB}^{+}$ & $-/ \mathrm{LBB}^{-}$ & $-/ \mathrm{LBB}^{-}$ & $-/ \mathrm{LBB}^{-}$ & $-/ \mathrm{LBB}^{-}$ \\
\hline
\end{tabular}

${ }^{a}$ Growth over time was monitored based on $\mathrm{OD}_{600}$ measurements for isolates cultured in liquid medium (AB_14 and TB-2 at pH 5.5 and AB_18 at pH 7).

${ }^{b}$ Growth (+) or no growth $(-) /$ presence of Mn oxides $\left(\mathrm{LBB}^{+}\right)$or no evidence of $\mathrm{Mn}$ oxidation $\left(\mathrm{LBB}^{-}\right)$. 

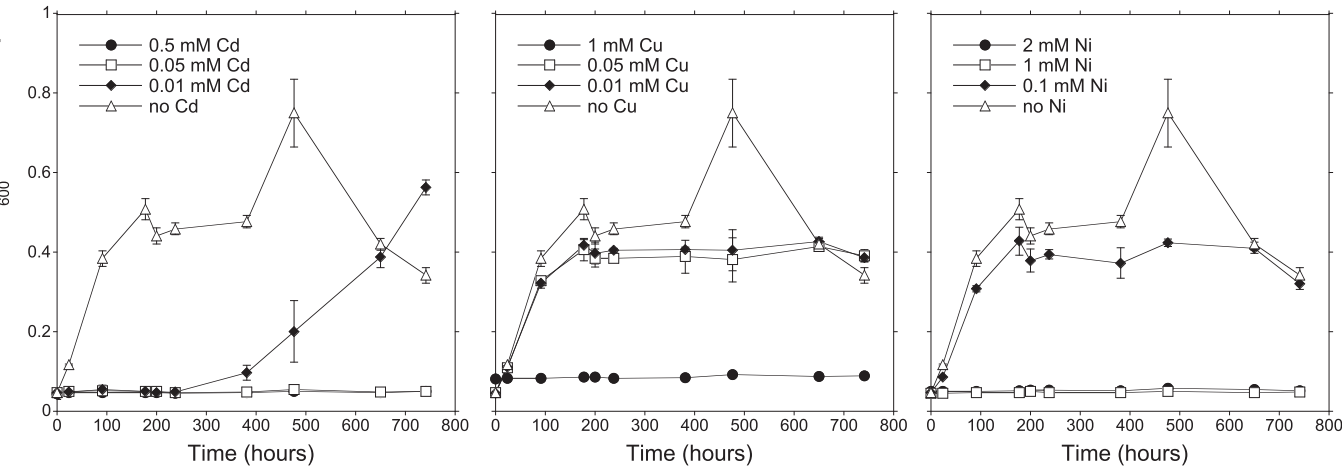

AB_18
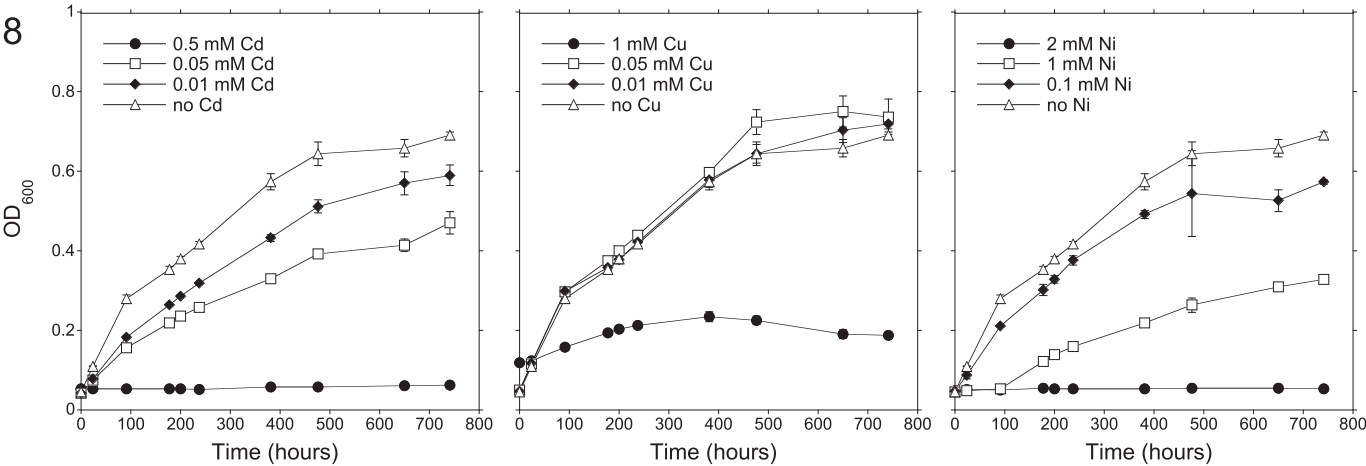

TB-2
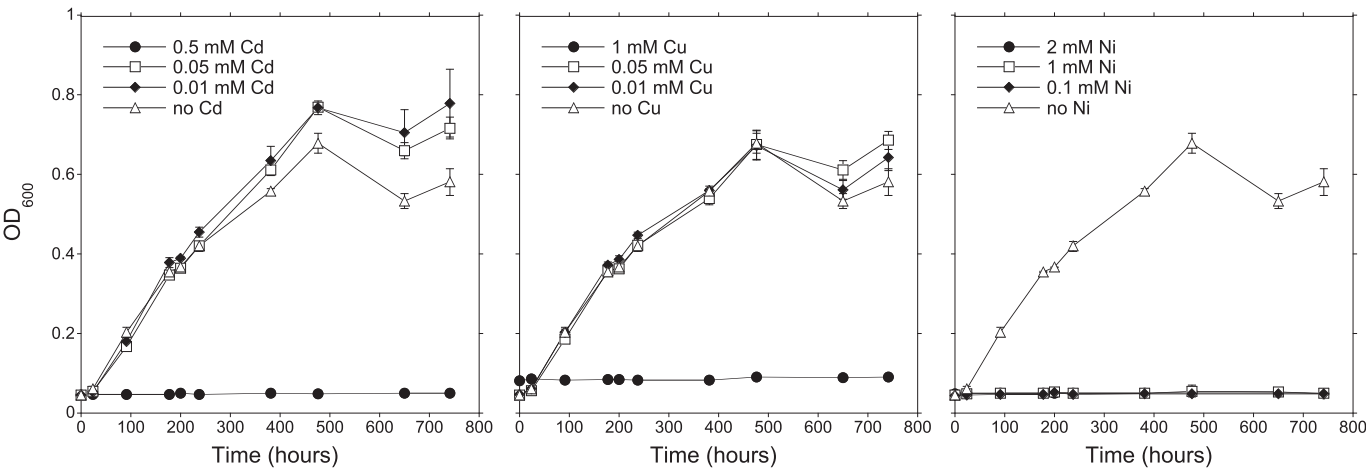

B

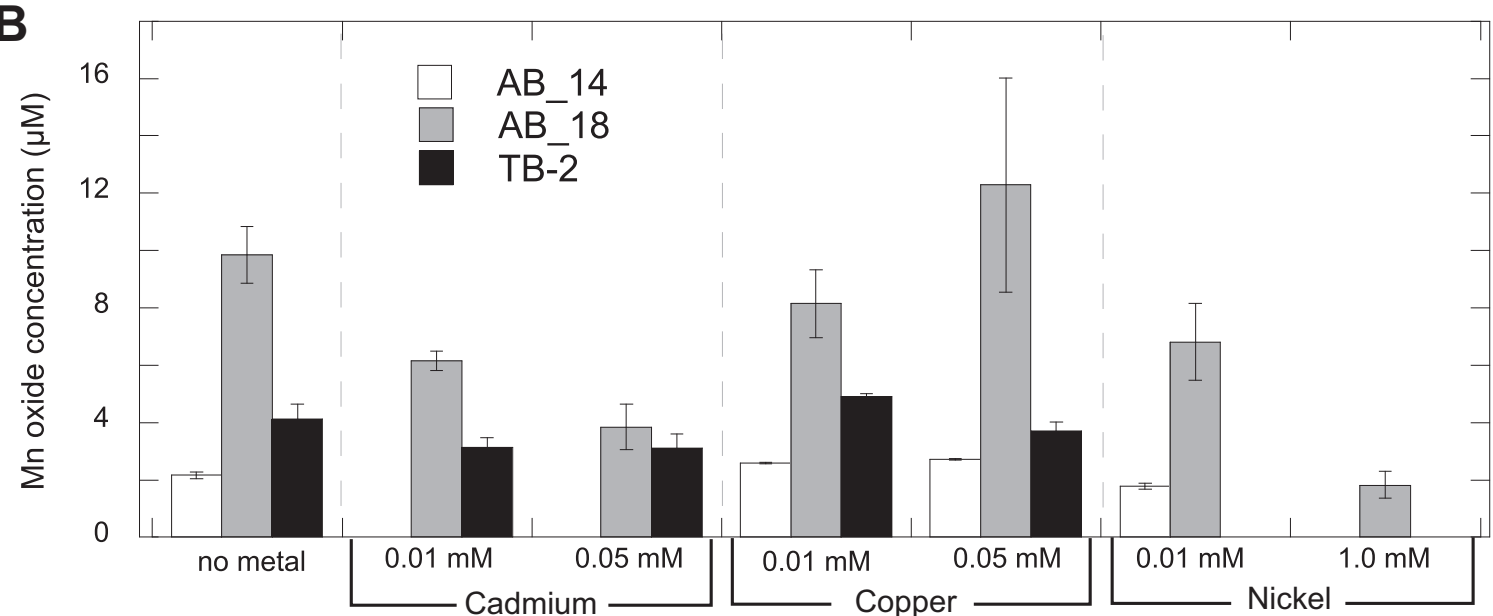

Metal Treatment

FIG 2 Growth of (A) and Mn oxide production by (B) strains AB_14, AB_18, and TB-2 in the presence of various concentrations of Cd, Cu, and Ni. Growth over time was monitored by $\mathrm{OD}_{600}$ measurements of isolates cultured in liquid medium (AB_14 and TB-2 at pH 5.5, AB_18 at pH 7). Mn oxides were measured using the LBB colorimetric assay after $742 \mathrm{~h}$ of growth. All values are means of triplicate cultures minus the concentrations of control cultures (uninoculated media) \pm standard deviations. Omitted values indicate no growth under the experimental conditions. 

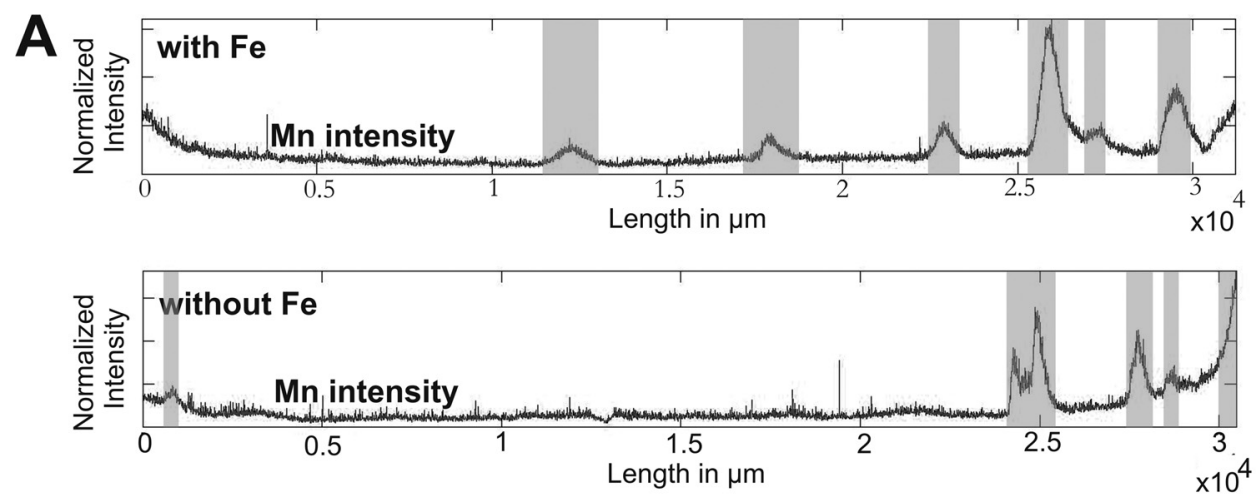

Scan direction
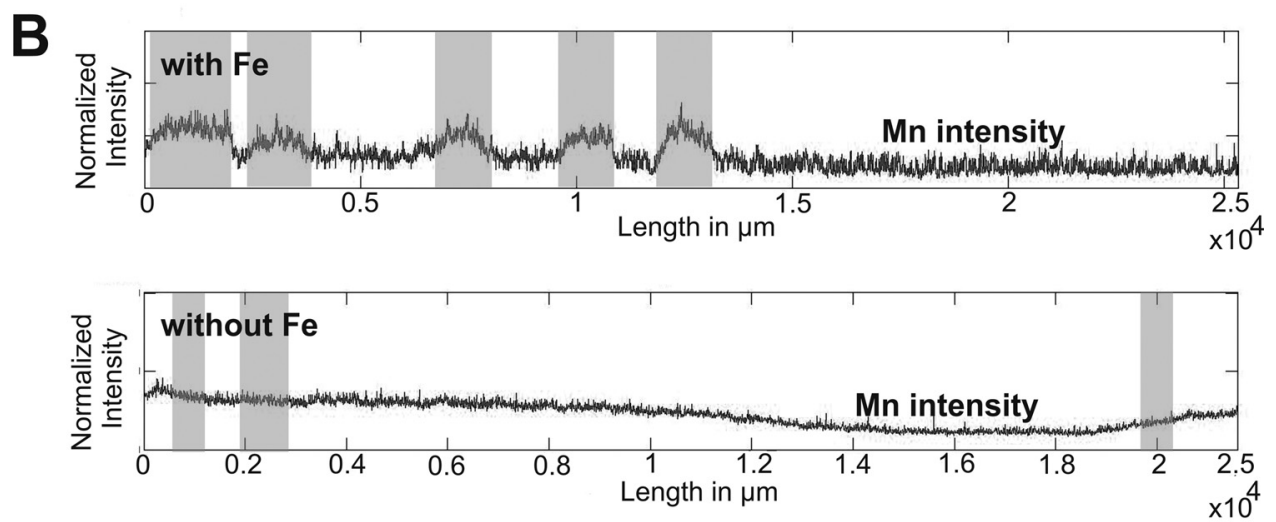

Legend:

\section{indicates area of colony growth on agar plate}

FIG 3 Elemental distributions of strains AB_14 (pH 5.5) (A) and AB_9 (pH 7) (B) grown in BM medium with or without iron, determined using LA-ICP-MS. The graphs show the signal intensities of $\mathrm{Mn}$ depending on the position of bacterial biomass on the agar plate (gray bars) and the availability of Fe. The intensities were normalized to an internal standard (carbon).

presence of metals (Ni, Cd, and $\mathrm{Cu}$ ) (Table 3 and Fig. 2). With Ni and $\mathrm{Cu}, \mathrm{AB} \_14$ grew faster than the other isolates, reaching stationary phase at around $200 \mathrm{~h}$ (Fig. 2A). While AB_14 was sensitive to $\mathrm{Cd}$ in the early stages of growth, it grew with $\mathrm{Cd}$ after a 10-day lag phase (Fig. 2A). AB_18 tolerated all 3 metals but grew the slowest and did not reach stationary phase until $\sim 500 \mathrm{~h}$ (Fig. 2A). Interestingly, although Arthrobacter sp. AB_18 grew in the presence of $1.0 \mathrm{mM} \mathrm{Cu}$, it only oxidized $\mathrm{Mn}$ in less than $0.05 \mathrm{mM}$ $\mathrm{Cu}$ (Table 3 and Fig. 2B). Additionally, AB_18 oxidized more Mn than the other strains (Fig. 2B).

Soil pore water concentrations of $\mathrm{Ni}(170 \mu \mathrm{M}), \mathrm{Cu}(6 \mu \mathrm{M})$, and $\mathrm{Cd}(0.5 \mu \mathrm{M})$ at GTF (see Fig. S2 in the supplemental material) and water $(8.5 \mu \mathrm{M} \mathrm{Ni}$ and $0.013 \mu \mathrm{M} \mathrm{Cd}$; $\mathrm{Cu}$ was not determined) from Gessen Creek (31) both had lower metal concentrations than those tolerated by our strains. However, our isolates tolerated higher metal concentrations than what typically inhibits Mn oxidation by the model MOB, Leptothrix discophora SS-1 [ $\mathrm{Zn}(\mathrm{II})$ and $\mathrm{Co}(\mathrm{II})$ at $10 \mu \mathrm{M}$ and $\mathrm{Cu}(\mathrm{II})$ and $\mathrm{Ni}(\mathrm{II})$ at $100 \mu \mathrm{M}]$ (52). This suggests that our strains are well adapted to the metal-contaminated conditions at the Ronneburg sites.

Although members of the Duganella genus, which contains our $\mathrm{AB} \_14$ isolate, have been isolated from metal-contaminated environments, little is known about the specific metal tolerance of these species. For example, Duganella strain EK-I49, which was isolated from metal-contaminated soils in Slovakia, contains the metal resistance ( $n c c A$ ) gene (53). Similarly, $\mathrm{HgCl}_{2}$-contaminated soils yielded another isolate with high sequence similarity to $D$. violaceusnigra (54). The metal tolerance we observed in Arthrobacter isolate $\mathrm{AB} \_18$ is consistent with other Arthrobacter strains that are well known for their extremely high metal tolerance (55-57). Albidiferax ferrireducens, the closest relative of isolate TB-2, is yet to be evaluated for metal tolerance; therefore, TB-2 tolerance to up to $0.05 \mathrm{mM} \mathrm{Cd}$ and $\mathrm{Cu}$ expands the known physiology of this organism.

The enzymes responsible for microbial Mn oxidation include calcium-binding heme peroxidases (MopA) and multicopper oxidases (MCO) (summarized in reference 4). MCO catalyze the transfer of electrons not only to Mn but also to Fe(II) and other substrates (58). Copper ions are necessary for MCO enzyme function, and our isolates AB_14, AB_18, and TB-2 grew and oxidized $\mathrm{Mn}$ in the presence of 0.01 and $0.05 \mathrm{mM} \mathrm{Cu}$ in the medium. These strains were also less sensitive to copper than nickel at the same concentrations. Further work is needed to determine whether the addition of copper enhances Mn oxidation in these strains, which could indicate the presence of an MCO or other oxidant.

Elemental distribution in MOB biomass. LA-ICP-MS was used to obtain spatially resolved information on the elemental distribution of $\mathrm{Mn}$ and Fe within MOB biomass and surrounding 

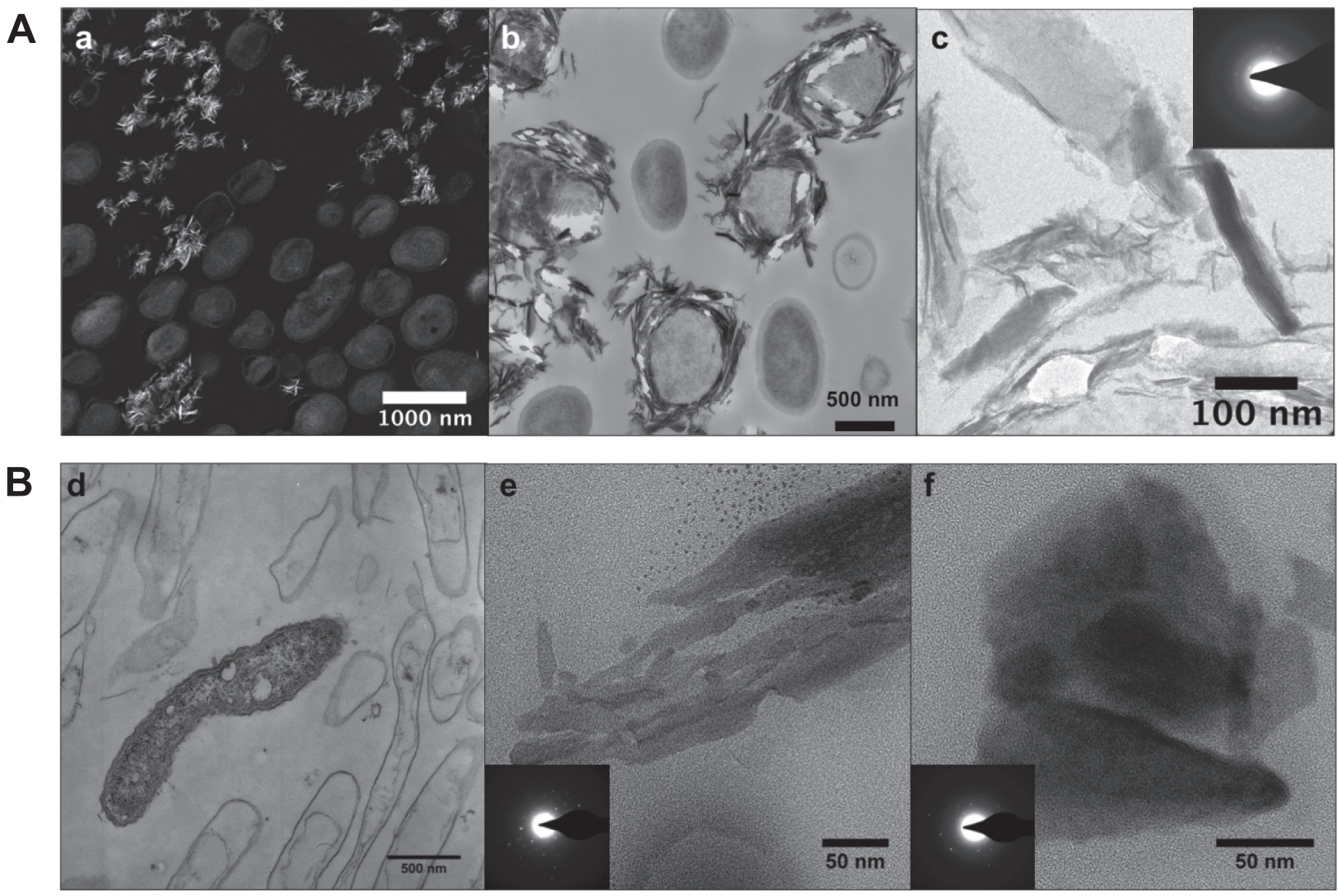

FIG 4 TEM images of AB_18 and AB_14 cells and Mn oxides. (A) AB_18. (a) STEM high-angle annular dark-field (HAADF) image (the brighter areas indicate higher Z elements); (b) TEM image of Mn oxide minerals surrounding some cells; (c) TEM image of a cluster of minerals and their selected area diffraction patterns, showing some crystallinity (inset). (B) AB_14. TEM images with diffraction patterns (insets) of live and mostly dead bacteria with few obvious minerals around them (d) or aggregates of Mn oxide particles (e and f). Diffraction areas were larger than the images shown.

agar medium. Generally, high Mn intensities were associated with microbial biomass for all investigated strains (as displayed for two examples in Fig. 3). In contrast, the LA-ICP-MS transect showed that areas of agar without biomass had constant element intensities except for the beginning and end regions for the Mn measurement. The cause of these unusual Mn intensities is likely the sample preparation, which resulted in higher dehydration of the agar pieces on the end, causing them to show higher Mn background levels.

As the medium initially used to isolate our organisms also contained $\mathrm{Fe}(\mathrm{II})$, the ability of the organisms to also oxidize $\mathrm{Fe}(\mathrm{II})$ may have led to enzymatic Fe oxidation that then may have triggered Mn(II) oxidation (59). Thus, LA-ICP-MS was used to evaluate if the coenrichment of $\mathrm{Mn}$ and $\mathrm{Fe}$ was due to oxidation of the Fe in the medium by MOB strains AB_9 ( $\mathrm{pH} 7)$ and AB_14 (pH 5.5). The LA-ICP-MS profile for strain AB_14 (pH 5.5) (Fig. 3A) showed an enrichment of $\mathrm{Mn}$ in the bacterial biomass both with and without $\mathrm{Fe}$ in the medium, suggesting that secondary abiotic oxidation of Mn was not occurring. However, the model Mn(II) oxidizer $P$. putida GB-1 uses different pathways for Mn oxidation, depending on iron availability $(60,61)$. Under iron-replete conditions, enzymatic Mn oxidation is hypothesized to predominate, whereas under iron-limited conditions siderophore production is linked to abiotic oxidation (61). Further work is needed to deter- mine whether AB_14 uses a single pathway for Mn oxidation or whether this strain produces siderophores that contribute to abiotic Mn oxidation. In contrast to $\mathrm{AB} \_14$, the other Duganella sp. strain, AB_9, isolated at pH 7 (Fig. 3B) did not accumulate Mn in its biomass in the absence of Fe. This suggests a linkage between $\mathrm{Fe}$ and $\mathrm{Mn}$ oxidation in strain AB_9, either through biological Fe(II) oxidation followed by secondary abiotic oxidation of $\mathrm{Mn}$ or via the iron-dependent enzymatic Mn(II) oxidation that is observed in P. putida GB-1 (61). In addition, this observation highlighted the physiological differences between strains AB_9 and AB_14, such as the presence of different Mn oxidation pathways and siderophore production in AB_14. Determining the mechanisms for Mn oxidation at low pH by isolate Duganella sp. AB_14 will be aided by genome queries, as the full-genome sequencing is under way in collaboration with the Joint Genome Institute.

Identification of biogenic Mn oxides. Mn oxides produced by Ronneburg isolates were identified using FTIR spectroscopy and TEM. FTIR spectra of all representative strains that produced precipitates showed a slightly higher absorbance between 750 and 400 $\mathrm{cm}^{-1}$, which is characteristic for the Mn-O vibrations of the $\mathrm{MnO}_{6}$ octahedral framework in Mn oxides (see Fig. S3 in the supplemental material). TEM revealed mineral-cell associations for the Mn oxides produced by isolates Arthrobacter sp. AB_18 and Duganella sp. AB_14 (Fig. 4). Many AB_18 cells were en- 

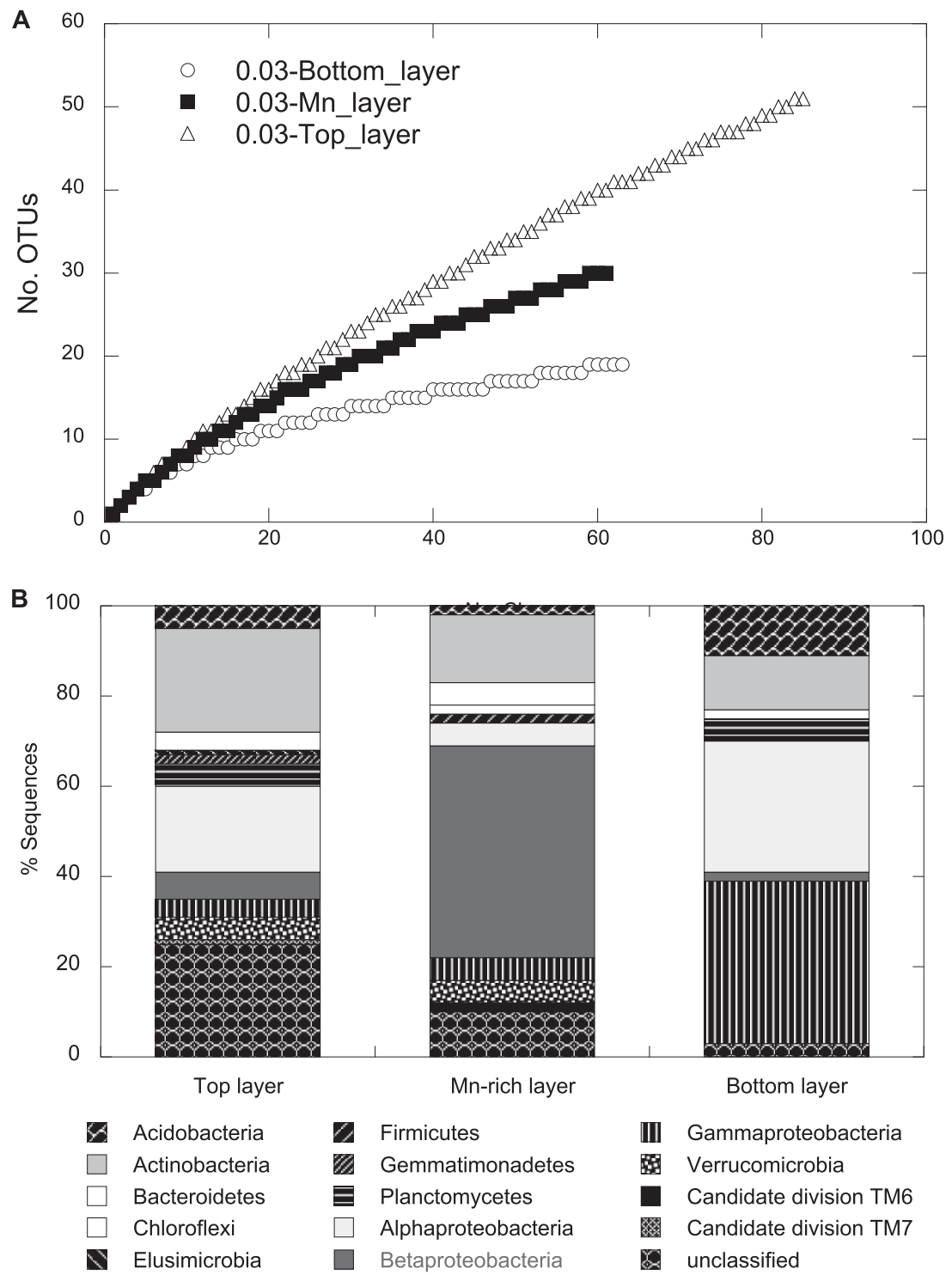

FIG 5 Rarefaction curves (A) and frequencies of bacterial phylogenetic lineages (B) for the 16S rRNA gene clone libraries obtained for the three subsurface layers, $\mathrm{Mn}$-rich, top, and bottom at the GTF site. A total of 85, 61, and 63 clones were analyzed for the top, Mn-rich, and bottom layers, respectively. Phylogenetic affiliations of OTUs (based on a $>97 \%$ sequence similarity cutoff) were determined by using mothur against the SILVA database. Frequencies were based on the total number of clones associated with OTUs of sequenced representatives at the phylum level or class level for Proteobacteria.

crusted with Mn oxides (Fig. 4B); in contrast, AB_14 cells were not encrusted and $\mathrm{Mn}$ oxide precipitates were only observed away from the cells (Fig. 4A). EDS showed that the precipitates were composed of $\mathrm{Mn}$ and $\mathrm{O}$ along with other elements from the embedding resin (see Fig. S4 in the supplemental material). Analysis of SAED patterns showed crystallographic d-spacings similar to those of common Mn oxides (birnessite and todorokite), although they could not be conclusively identified (see Table S1 in the supplemental material).

The observed locations of the minerals on the bacteria may also indicate a potential role and/or mechanism for Mn oxidation. Our Arthrobacter sp. AB_18 was encrusted with a difficult-to-identify Mn oxide mineral (see Table S1), suggesting a direct mechanism of oxidation such as enzymatic oxidation on the outer membrane (2). The encrusted Mn oxides on the cell may be acting as a pro- tective barrier from toxic metal ions, which would impart a selective advantage for such organisms in the metal-contaminated environments at the Ronneburg area. Mn oxides from Duganella sp. AB_14 differed in morphology from those from strain AB_18 and were not observed in close proximity to the cell. This may indicate that low-pH oxidation proceeds via a different enzymatic pathway than that used by Mn-oxidizing organisms found in neutral-pH samples, or that Mn oxidation occurs via indirect mechanisms, such as the production of superoxides (17). Recently, extracellular superoxide production was found to be widespread among heterotrophic bacteria, although the two Betaproteobacteria species tested were not shown to produce superoxide (62). However, additional Betaproteobacteria strains may prove to produce superoxide or other reactive oxygen species, as their production is ubiquitous among both bacteria and fungi (62). 
Microbial community analysis. Total relative bacterial abundance was low in subsurface soils at site GTF with the soil layer above (top), the Mn-rich geochemical barrier, and the layer below (bottom), as we found $6.6 \times 10^{4}, 8.5 \times 10^{5}$, and $6.1 \times 10^{5} 16 \mathrm{~S}$ rRNA gene copies per gram (wet weight) of soil, respectively (determined using $\mathrm{qPCR}$ ). For comparative microbial community analysis, a $16 \mathrm{~S}$ rRNA gene cloning and sequencing approach revealed a total of 209 sequences that grouped into 91 OTUs, with 4 OTUs present in all 3 libraries. Rarefaction analysis indicated saturation of sampling for the bottom sample but not for the Mnrich or top samples (Fig. 5A), and coverage had a similar pattern (see Table S2 in the supplemental material). The community composition in the Mn-rich geochemical barrier differed distinctly from those of the top and bottom communities (Fig. 5B), with a dominance of Betaproteobacteria ( $47 \%$ of total clones). The Betaproteobacteria-related clone Mn_DNA_21 was most closely related to isolate TB-2 from the Mn-rich layer and to A. ferrireducens and represented $\sim 16 \%$ of total clones, suggesting a high in situ prevalence of this isolate at the former leaching heap site GTF (Fig. 1). The abundance of $A$. ferrireducens in the $\mathrm{Mn}$-rich geochemical barrier was $\sim 10^{5} 16 \mathrm{~S}$ rRNA gene copies per $\mathrm{g}$ (wet weight) of sediment as revealed by qPCR, representing $13.5 \%$ of the total bacterial community. As shown in a parallel study by Fabisch et al. (31), this bacterial group represents $27 \%$ of the total community in the sediment of the Gessen Creek site (R3), where bacterial $16 \mathrm{~S}$ rRNA gene copy numbers per $\mathrm{g}$ (wet weight) of sediment are 5 orders of magnitude higher than at site GTF. Members of the Alphaproteobacteria dominated the bottom layer ( $29 \%$ of total clones). Clones related to members of the Actinobacteria represented $23 \%, 15 \%$, and $12 \%$ of total clones in the top, Mn-rich, and bottom layers, respectively (Fig. 5B).

Some RNA- and DNA-derived 16S rRNA clones from Gessen Creek sediment R3 obtained in the study of Fabisch et al. (31) are related to known $\mathrm{MOB}$ and to two of the MOB isolates obtained in this study. The RNA-derived clones included members from Actinobacteria (Arthrobacter related), Bacteroidetes (Flavobacterium sp.), Gammaproteobacteria (Acinetobacter sp.), and Betaproteobacteria (Albidiferax sp.) (31). The detection of these organisms on the RNA level indicates their potential activities within the environment. The presence of a DNA-based clone related to the $O x$ alobacteraceae family (31) was interesting, as this is the same family as our low-pH isolate $\mathrm{AB} \_14$ and suggests that this organism has the potential to be active at the Gessen Creek site.

We have provided evidence that MOB isolates obtained from the former Ronneburg uranium mining area could impact the fate of metal contaminants via adsorption to biogenic Mn oxide minerals formed at both acidic and neutral pHs. In many metal-contaminated environments, biological Mn oxidation is associated with a decrease in aqueous metal load. The biogenic minerals produced by our isolates at pH 5.5 (Duganella $\mathrm{AB}_{-} 14$ ) and 7.0 (Arthrobacter $\mathrm{AB} \_18$ ) were difficult to conclusively identify. However, birnessite and todorokite comprised the $\mathrm{Mn}$-rich layer at site GTF (M. Händel, personal communication, and (26)) where accumulation of metals was associated with Mn oxides. Although we do not show direct evidence that MOB formed the Mn oxides in the acidic Mn-rich geochemical barrier, the stability of $\mathrm{Mn}$ (II) under the environmental conditions is such that Mn oxides are not predicted to form under solely abiotic conditions $(2,5,6)$. In addition, our Albidiferax strain TB-2 ( $\mathrm{pH}$ 5.5) isolate was closely related to a clone from the Mn-rich layer that had a high relative contribution ( $16 \%$ total clones) to the in situ community. As strain TB-2 oxidizes $\mathrm{Mn}$ in the lab under $\mathrm{pH}$ levels that are relevant to in situ conditions, we can infer that this organism may be involved in biological Mn oxidation at the site, and further work is needed to assess the potential for biogenic Mn oxides to contribute to metal attenuation in the Mn-rich layer.

\section{ACKNOWLEDGMENTS}

We thank M. Fabisch, F. Beulig, P. Bouwma, and S. Lu (Aquatic Geomicrobiology, FSU Jena) for help with sampling. S. Nietzsche and C. Kämnitz of the Electron Microscopy Center at the University Clinic, FSU Jena, performed resin embedding and some TEM. The Ernst-Ruska Centre for Microscopy and Spectroscopy with Electrons user facility in Jülich, Germany, provided free access to and assistance with TEM. We thank Darren Dunlap for helpful discussions.

We also thank the German Science Foundation (DFG GRK 1257) for funding.

Any use of trade, product, or firm names is for descriptive purposes only and does not imply endorsement by the U.S. Government.

\section{REFERENCES}

1. Morgan JJ. 2005. Kinetics of reaction between $\mathrm{O}_{2}$ and $\mathrm{Mn}$ (II) species in aqueous solutions. Geochim. Cosmochim. Acta 69:35-48. http://dx.doi .org/10.1016/j.gca.2004.06.013.

2. Tebo BM, Bargar JR, Clement BG, Dick GJ, Murray KJ, Parker D, Verity R, Webb SM. 2004. Biogenic manganese oxides: properties and mechanisms of formation. Annu. Rev. Earth Planet. Sci. 32:287-328. http: //dx.doi.org/10.1146/annurev.earth.32.101802.120213.

3. Tebo B, Clement B, Dick G. 2007. Biotransformations of manganese, p 1223-1238. In Hurst CJ (ed), Manual of environmental microbiology, 3rd ed. ASM Press, Washington, DC.

4. Geszvain K, Butterfield C, Davis R, Madison A, Lee S, Parker D, Soldatova A, Spiro T, Luther G, Tebo B. 2012. The molecular biogeochemistry of manganese(II) oxidation. Biochem. Soc. Trans. 40:12441248. http://dx.doi.org/10.1042/BST20120229.

5. Nealson KH. 2006. The manganese-oxidizing bacteria, p 222-231. In Balows A, Trüper HG, Dworkin M, Harder W, Schleifer K-H (ed), The prokaryotes. Springer, New York, NY.

6. Luther GW. 2010. The role of one-and two-electron transfer reactions in forming thermodynamically unstable intermediates as barriers in multielectron redox reactions. Aquat. Geochem. 16:395-420. http://dx.doi.org /10.1007/s10498-009-9082-3.

7. von Langen PJ, Johnson KS, Coale KH, Elrod VA. 1997. Oxidation kinetics of manganese (II) in seawater at nanomolar concentrations. Geochim. Cosmochim. Acta 61:4945-4954. http://dx.doi.org/10.1016 /S0016-7037(97)00355-4.

8. Hansel C, Francis C. 2006. Coupled photochemical and enzymatic $\mathrm{Mn}$ (II) oxidation pathways of a planktonic Roseobacter-like bacterium. Appl. Environ. Microbiol. 72:3543-3549. http://dx.doi.org/10.1128/AEM .72.5.3543-3549.2006.

9. Francis CA, Tebo BM. 1999. Marine Bacillus spores as catalysts for oxidative precipitation and sorption of metals. J. Mol. Microbiol. Biotechnol. 1:71-78.

10. Boogerd F, de Vrind J. 1987. Manganese oxidation by Leptothrix discophora. J. Bacteriol. 169:489-484.

11. Francis CA, Tebo BM. 2001. cumA multicopper oxidase genes from diverse $\mathrm{Mn}(\mathrm{II})$-oxidizing and non-Mn(II)-oxidizing Pseudomonas strains. Appl. Environ. Microbiol. 67:4272-4278. http://dx.doi.org/10 .1128/AEM.67.9.4272-4278.2001.

12. Anderson C, Dick G, Chu M, Cho J, Davis R, Bräuer S, Tebo B. 2009. Aurantimonas manganoxydans, sp. nov. and Aurantimonas litoralis, sp. nov.: $\mathrm{Mn}$ (II) oxidizing representatives of a globally distributed clade of alpha-Proteobacteria from the order Rhizobiales. Geomicrobiol. J. 26:189198. http://dx.doi.org/10.1080/01490450902724840.

13. Bromfield SM. 1979. Manganous ion oxidation at $\mathrm{pH}$ values below 5.0 by cell-free substances from Streptomyces sp. cultures. Soil Biol. Biochem. 11:115-118. http://dx.doi.org/10.1016/0038-0717(79)90086-5.

14. Bromfield S. 1956. Oxidation of manganese by soil microorganisms. Aust. J. Biol. Sci. 9:238-252. 
15. Ivarson K, Heringa P. 1972. Oxidation of manganese by microorganisms in manganese deposits of Newfoundland soil. Can. J. Soil Sci. 52:401-416. http://dx.doi.org/10.4141/cjss72-052.

16. Sparrow LA, Uren NC. 1987. Oxidation and reduction of Mn in acidic soils: effect of temperature and soil pH. Soil Biol. Biochem. 19:143-148. http://dx.doi.org/10.1016/0038-0717(87)90073-3.

17. Learman DR, Voelker BM, Vazquez-Rodriguez AI, Hansel CM. 2011. Formation of manganese oxides by bacterially generated superoxide. Nat. Geosci. 4:95-98. http://dx.doi.org/10.1038/ngeo1055.

18. Banh A, Chavez V, Doi J, Nguyen A, Hernandez S, Ha V, Jimenez P, Espinoza F, Johnson HA. 2013. Manganese (Mn) oxidation increases intracellular Mn in Pseudomonas putida GB-1. PLoS One 8:e77835. http: //dx.doi.org/10.1371/journal.pone.0077835.

19. Tebo BM, Johnson HA, McCarthy JK, Templeton AS. 2005. Geomicrobiology of manganese(II) oxidation. Trends Microbiol. 13:421-428. http: //dx.doi.org/10.1016/j.tim.2005.07.009.

20. Nelson Y, Lion L, Ghiorse W, Shuler M. 1999. Production of biogenic Mn oxides by Leptothrix discophora SS-1 in a chemically defined growth medium and evaluation of their $\mathrm{Pb}$ adsorption characteristics. Appl. Environ. Microbiol. 65:175-180.

21. Peña J, Kwon KD, Refson K, Bargar JR, Sposito G. 2010. Mechanisms of nickel sorption by a bacteriogenic birnessite. Geochim. Cosmochim. Acta 74:3076-3089. http://dx.doi.org/10.1016/j.gca.2010.02.035.

22. Wang W, Shao Z, Liu Y, Wang G. 2009. Removal of multi-heavy metals using biogenic manganese oxides generated by a deep-sea sedimentary bacterium Brachybacterium sp. strain Mn32. Microbiology 155:1989_ 1996. http://dx.doi.org/10.1099/mic.0.024141-0.

23. Toner B, Manceau A, Webb S, Sposito G. 2006. Zinc sorption to biogenic hexagonal-birnessite particles within a hydrated bacterial biofilm. Geochim. Cosmochim. Acta 70:27-43. http://dx.doi.org/10.1016/j.gca 2005.08.029.

24. Burkhardt E, Meißner S, Merten D, Büchel G, Küsel K. 2009. Heavy metal retention and microbial activities in geochemical barriers formed in glacial sediments subjacent to a former uranium mining leaching heap. Chem. Erde Geochem. 69:21-34. http://dx.doi.org/10.1016/j.chemer.2008.12.003.

25. Carlsson E, Büchel G. 2005. Screening of residual contamination at a former uranium heap leaching site, Thuringia, Germany. Chem. Erde Geochem. 65:75-95. http://dx.doi.org/10.1016/j.chemer.2005.06.007.

26. Schäffner F. 2013. Natural attenuation of heavy metals in near-surface supergene Mn deposits occurring at the basement of a former leaching heap, Ronneburg, Germany. Ph.D. dissertation. Friedrich-Schiller University Jena, Jena, Germany.

27. Perel'man AI. 1967. Geochemistry of epigenesis, p 213-234. Plenum Press, New York, NY.

28. Grawunder A, Lonschinski M, Merten D. 2009. Distribution and bonding of residual contamination in glacial sediments at the former uranium mining leaching heap of Gessen/Thuringia, Germany. Chem. Erde Geochem. 69:5-19. http://dx.doi.org/10.1016/j.chemer.2008.06.001.

29. Küsel K, Ewald E-M, Sitte J. 2008. Effect of metal-reducing microorganisms on element fluxes in a former uranium-mining district, p 128-137. In Liu S-J, Drake HL (ed), Microbes in the environment: perspectives and challenges. Science Press, Beijing, China.

30. Deutsches Institut fur Normung. 2000. 19684-1:1977-02. Methods of soil analysis for water management for agricultural purposes: chemical laboratory tests; determination of $\mathrm{pH}$-value of the soil and lime requirement. Handbuch der Bodenuntersuchung. Beuth Verlag, Berlin, Germany.

31. Fabisch M, Beulig F, Akob DM, Küsel K. 2013. Surprising abundance of Gallionella-related iron oxidizers in creek sediments at $\mathrm{pH} 4.4$ or at high heavy metal concentrations. Front. Microbiol. 4:390. http://dx.doi.org/10 .3389/fmicb.2013.00390.

32. Mulder EG, van Veen WL. 1963. Investigations on the SphaerotilusLeptothrix group. Antonie Van Leeuwenhoek 29:121-153.

33. Benz M, Brune A, Schink B. 1998. Anaerobic and aerobic oxidation of ferrous iron at neutral $\mathrm{pH}$ by chemoheterotrophic nitrate-reducing bacteria. Arch. Microbiol. 169:159-165. http://dx.doi.org/10.1007/s002030050555.

34. Krumbein W, Altmann H. 1973. A new method for the detection and enumeration of manganese oxidizing and reducing microorganisms. Helgol. Mar. Res. 25:347-356.

35. Lu S, Gischkat S, Reiche M, Akob DM, Hallberg KB, Küsel K. 2010. Ecophysiology of Fe-cycling bacteria in acidic sediments. Appl. Environ. Microbiol. 76:8174-8183. http://dx.doi.org/10.1128/AEM.01931-10.

36. Drummond A, Ashton B, Buxton S, Cheung M, Cooper A, Duran C, Field M, Heled J, Kearse M, Markowitz S, Moir R, Stones-Havas S,
Sturrock S, Thierer T, Wilson A. 2009. Geneious v4.6.0. Biomatters, Auckland, New Zealand.

37. Altschul SF, Gish W, Miller W, Myers EW, Lipman DJ. 1990. Basic loca alignment search tool. J. Mol. Biol. 215:403-410. http://dx.doi.org/10 .1016/S0022-2836(05)80360-2.

38. Chun J, Lee JH, Jung Y, Kim M, Kim S, Kim BK, Lim YW. 2007. EzTaxon: a Web-based tool for the identification of prokaryotes based on $16 \mathrm{~S}$ ribosomal RNA gene sequences. Int. J. Syst. Evol. Microbiol. 57:22592261. http://dx.doi.org/10.1099/ijs.0.64915-0.

39. Ludwig W, Strunk O, Westram R, Richter L, Meier H, Yadhukumar Buchner A, Lai T, Steppi S, Jobb G, Forster W, Brettske I, Gerber S, Ginhart AW, Gross O, Grumann S, Hermann S, Jost R, Konig A, Liss T, Lussmann R, May M, Nonhoff B, Reichel B, Strehlow R, Stamatakis A, Stuckmann N, Vilbig A, Lenke M, Ludwig T, Bode A, Schleifer K-H. 2004. ARB: a software environment for sequence data. Nucleic Acids Res. 32:1363-1371. http://dx.doi.org/10.1093/nar/gkh293.

40. de Vrind JP, Boogerd FC, de Vrind-de Jong EW. 1986. Manganese reduction by a marine Bacillus species. J. Bacteriol. 167:30-34.

41. Zhou JZ, Bruns MA, Tiedje JM. 1996. DNA recovery from soils of diverse composition. Appl. Environ. Microbiol. 62:316-322.

42. Schloss PD, Westcott S, Ryabin T, Hall J, Hartmann M, Hollister E, Lesniewski R, Oakley B, Parks D, Robinson C, Sahl J, Stres B, Thallinger G, Van Horn D, Weber C. 2009. Introducing mothur: open-source, platform-independent, community-supported software for describing and comparing microbial communities. Appl. Environ. Microbiol. 75:7537-7541. http://dx.doi.org/10.1128/AEM.01541-09.

43. Lane DJ. 1991. 16S/23S rRNA sequencing in E. coli, p 115-175. In Stackebrandt E, Goodfellow M (ed), Nucleic acid techniques in bacterial systematics. John Wiley \& Sons, New York, NY.

44. Zhou J. 2008. The development of molecular tools for the evaluation of the bioremediation of chlorinated solvents. Ph.D. dissertation. Utah State University, Logen, UT.

45. Lu S, Chourey K, Reiche M, Nietzsche S, Shah MB, Neu TR, Hettich RL, and Küsel K. 2013. Insights into the structure and metabolic function of microbes that shape pelagic iron-rich aggregates ("iron snow”). Appl. Environ. Microbiol. 79:4272-4281. http://dx.doi.org/10 .1128/AEM.00467-13.

46. Löffler S. 2007. Charakterisierung der geochemischen Barrieren im Gessenbach. Ph.D. dissertation. Friedrich Schiller University Jena, Jena, Germany.

47. Finneran KT, Johnsen CV, Lovley DR. 2003. Rhodoferax ferrireducens sp. nov., a psychrotolerant, facultatively anaerobic bacterium that oxidizes acetate with the reduction of Fe(III). Int. J. Syst. Evol. Microbiol. 53:669673. http://dx.doi.org/10.1099/ijs.0.02298-0.

48. Ramana CV, Sasikala C. 2009. Albidoferax, a new genus of Comamonadaceae and reclassification of Rhodoferax ferrireducens (Finneran et al., 2003) as Albidoferax ferrireducens comb. nov. J. Gen. Appl. Microbiol. 55:301-304. http://dx.doi.org/10.2323/jgam.55.301.

49. Takeda M, Kamagata Y, Ghiorse WC, Hanada S, Koizumi J-I. 2002. Caldimonas manganoxidans gen. nov., sp. nov., a poly(3-hydroxybutyrate)degrading, manganese-oxidizing thermophile. Int. J. Syst. Evol. Microbiol. 52:895-900. http://dx.doi.org/10.1099/ijs.0.02027-0.

50. Lincoln SP, Fermor TR, Tindall BJ. 1999. Janthinobacterium agaricidamnosum sp. nov., a soft rot pathogen of Agaricus bisporus. Int. J. Syst. Bacteriol. 49:1577-1589. http://dx.doi.org/10.1099/00207713-49-4-1577.

51. Carmichael MJ, Carmichael SK, Santelli CM, Strom A, Bräuer SL. 2013. $\mathrm{Mn}(\mathrm{II})$-oxidizing bacteria are abundant and environmentally relevant members of ferromanganese deposits in caves of the Upper Tennessee River Basin. Geomicrobiol. J. 30:779-800. http://dx.doi.org/10.1080 /01490451.2013.769651.

52. Miyata N, Tani Y, Sakata M, Iwahori K. 2007. Microbial manganese oxide formation and interaction with toxic metal ions. J. Biosci. Bioeng. 104:1-8. http://dx.doi.org/10.1263/jbb.104.1.

53. Karelová E, Harichová J, Stojnev T, Pangallo D, Ferianc P. 2011. The isolation of heavy-metal resistant culturable bacteria and resistance determinants from a heavy-metal-contaminated site. Biologia 66:18-26. http: //dx.doi.org/10.2478/s11756-010-0145-0.

54. Mera N, Iwasaki K. 2007. Use of plate-wash samples to monitor the fates of culturable bacteria in mercury- and trichloroethylene-contaminated soils. Appl. Microbiol. Biotechnol. 77:437-445. http://dx.doi.org/10.1007 /s00253-007-1152-0.

55. Margesin R, Schinner F. 1996. Bacterial heavy metal-tolerance-extreme 
resistance to nickel in Arthrobacter spp. strains. J. Basic Microbiol. 36:269282. http://dx.doi.org/10.1002/jobm.3620360410.

56. Benyehuda G, Coombs J, Ward PL, Balkwill D, Barkay T. 2003. Metal resistance among aerobic chemoheterotrophic bacteria from the deep terrestrial subsurface. Can. J. Microbiol. 49:151-156. http://dx.doi.org/10 $.1139 / \mathrm{w} 03-012$.

57. Abou-Shanab RA, van Berkum P, Angle JS. 2007. Heavy metal resistance and genotypic analysis of metal resistance genes in gram-positive and gram-negative bacteria present in Ni-rich serpentine soil and in the rhizosphere of Alyssum murale. Chemosphere 68:360-367. http://dx.doi.org /10.1016/j.chemosphere.2006.12.051.

58. Kosman D. 2010. Multicopper oxidases: a workshop on copper coordination chemistry, electron transfer, and metallophysiology. J. Biol. Inorg. Chem. 15:15-28. http://dx.doi.org/10.1007/s00775-009-0590-9.

59. Junta JL, Hochella MF, Jr. 1994. Manganese(II) oxidation at mineral surfaces: a microscopic and spectroscopic study. Geochim. Cosmochim. Acta 58:49854999. http://dx.doi.org/10.1016/0016-7037(94)90226-7.

60. Parker DL, Sposito G, Tebo BM. 2004. Manganese(III) binding to a pyoverdine siderophore produced by a manganese(II)-oxidizing bacterium. Geochim. Cosmochim. Acta 68:4809-4820. http://dx.doi.org/10 .1016/j.gca.2004.05.038.

61. Parker DL, Morita T, Mozafarzadeh ML, Verity R, McCarthy JK, Tebo BM. 2007. Inter-relationships of $\mathrm{MnO}_{2}$ precipitation, siderophore$\mathrm{Mn}$ (III) complex formation, siderophore degradation, and iron limitation in $\mathrm{Mn}$ (II)-oxidizing bacterial cultures. Geochim. Cosmochim. Acta 71: 5672-5683. http://dx.doi.org/10.1016/j.gca.2007.03.042.

62. Diaz JM, Hansel CM, Voelker BM, Mendes CM, Andeer PF, Zhang T. 2013. Widespread production of extracellular superoxide by heterotrophic bacteria. Science 340:1223-1226. http://dx.doi.org/10.1126 /science.1237331. 